\title{
Sepsisli Neonatal Buzağılarda Bazı hematolojik ve Biyokimyasal Parametrelerin Araştırılması
}

\author{
Investigation of Some Hematolojic and Biachemical Parameters in Neonatal Calves with Sepsis
}

\section{Yasemin BEYDİLLİ ${ }^{*}$ (D) Halil İbrahim GÖKÇE ${ }^{2}$ (D)}

${ }^{1}$ Mehmet Akif Ersoy University, Agriculture, Livestock and Food Research and Application Center, Burdur, Turkey ${ }^{2}$ Mehmet Akif Ersoy University, Faculty of Veterinary Medicine, Department of Internal Medicine, Burdur, Turkey

Öz: Çalışmanın amacı sepsisli neonatal buzağılarda hematolojik ve biyokimyasal değişimlerin araştrılıasıdır. Çalışmada, 20 adet sepsisli ve 10 adet klinik olarak sağılklı neonatal buzağ kullanıldı. Bütün buzağılar monitörize edildi ve pulse oksimetre ile oksijen satürasyonları $\left(\mathrm{SpO}_{2}\right)$ ölçüldü. Çalş̧mada yer alan tüm buzağıların hematolojik ve biyokimyasal analizleri yapıldı. Çalışmada sepsisli buzağıların vücut 1sısı $(\mathrm{p}<0.001)$ ve $\mathrm{SpO}_{2}(\mathrm{p}<0.01)$ değerleri düşük, solunum sayllarının $(\mathrm{p}<0.01)$ ise kontrol grubuna göre yüksek olduğu belirlendi. Sepsisli buzağııların total lökosit (WBC, $\mathrm{p}<0.001$ ), monosit (MID, $\mathrm{p}<0.001$ ), granülosit (GRA, $\mathrm{p}<0.01)$, ortalama korpuskuler volüm ( $\mathrm{MCV}, \mathrm{p}<0.01$ ), ortalama korpuskuler hemoglobin $(\mathrm{MCH}, \mathrm{p}<0.001)$ ve ortalama korpuskuler hemoglobin konsantrasyonu $(\mathrm{MCHC}$, $\mathrm{p}<0.01)$ düzeyleri kontrol grubu değerlerine göre yüksek bulundu. Ayrıca sepsisli buzağıların total bilirubin (T.BíL, $\mathrm{p}<0.01$ ), direkt bilirubin (D.Bİ, $\mathrm{p}<0.001$ ), üre (ÜRE, $\mathrm{p}<0.001$ ), kreatinin (KREA, $\mathrm{p}<0.001$ ), aspartat aminotrasferaz $($ AST, $\mathrm{p}<0.01$ ) ve laktat dehidrojenaz, $\mathrm{p}<0.001$ ) değerlerinde kontrol grubuna göre anlamlı artışlar saptanırken total protein (TP, $\mathrm{p}<0.01$ ), albümin (ALB, $\mathrm{p}<0.001$ ) ve immunoglobulin $(\mathrm{Ig}, \mathrm{p}<0.001)$ düzeylerinde ise önemli düzeyde düşüşler belirlendi. Yatar pozisyonda olan sepsisli (şiddetli) grupta ayakta olan (orta derecede) sepsisli buzağılara göre daha çok sayıda buzağıda hematolojik ve biyokimyasal parametrelerde değişimler belirlendi. Sonuç olarak sepsis neonatal buzağılarda önemli hematolojik ve biyokimyasal değişimlere neden olmakta ve kalp, karaciğer ve böbrekler gibi organların fonksiyonlarını negatif yönde etkilemektedir.

Anahtar Kelimeler: Biyokimya, Buzağı, Hematoloji, Monitörizasyon, Sepsis.

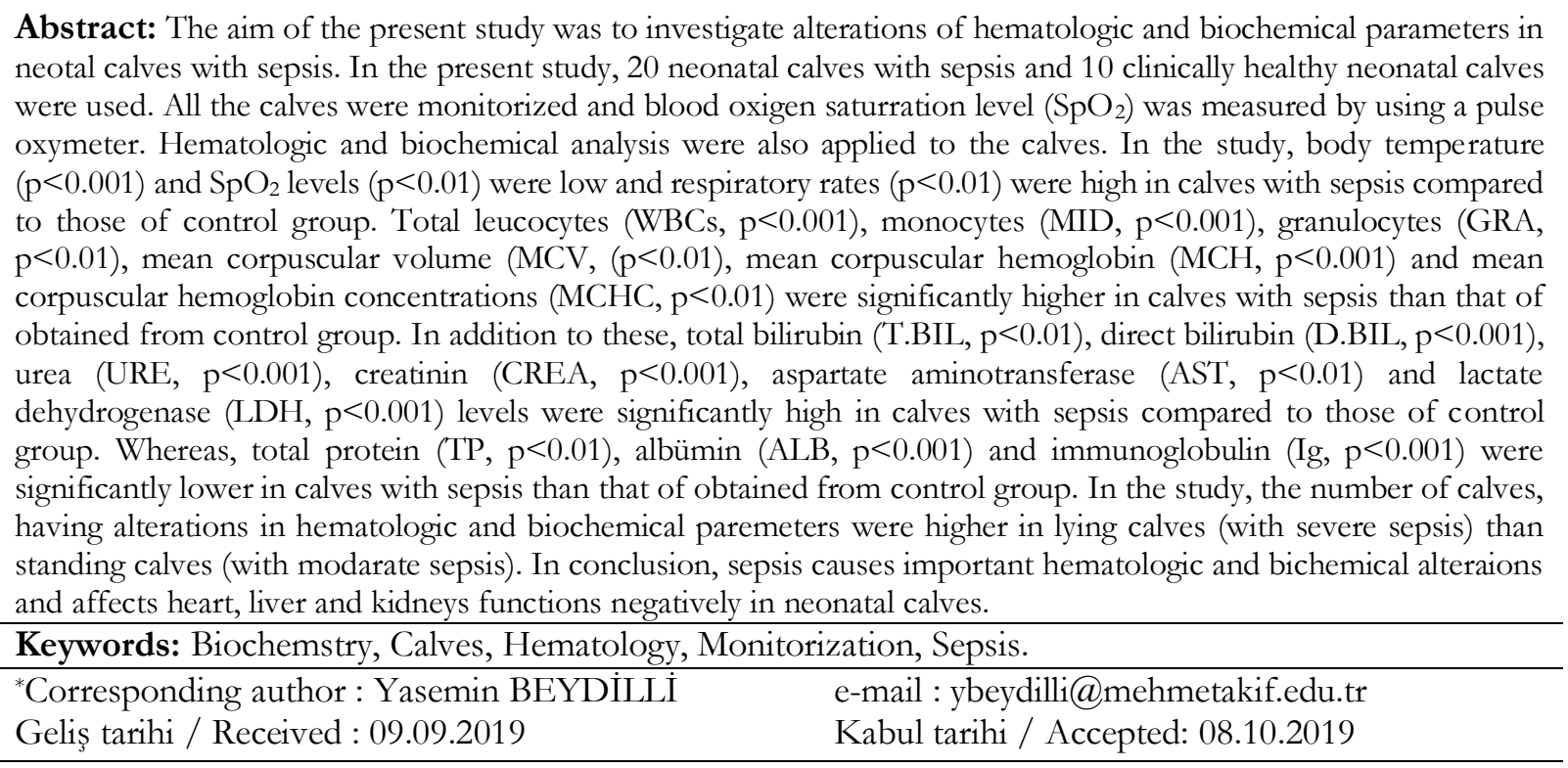




\section{Introduction}

Neonatal dönemde buzağılarda gelişen enfeksiyonlar yetişkin hayvanlara göre çok daha hızlı oluşmakta ve daha ciddi komplikasyonlarla sonuçlanmaktadır (Fecteau ve ark., 1997, Fectau ve ark, 2009, Şen ve ark., 2013, Cho ve Yoon, 2014, Smith, 2015, Bedenice ve ark., 2016, Poulsen ve ark., 2010, Pardon ve Depres, 2018). Enfeksiyonlar sonucu gelişen sepsisin yeterince şiddetli ve uzun sürmesi durumunda da dolaşımsal, hücresel ve metabolik bozukluklarla karakterize septik şok gelişmektedir. Septik şok; merkezi sinir sistemi, solunum sistemi, gastrointestinal sistem, kardiovasküler sistem ve hepatik sistem gibi birçok sistemin fonksiyonlarının bozulmasına ve çoklu organ yetmezliğinin gelişmesine neden olmaktadır. Çoklu organ yetmezliği ise sepsisin son aşaması olup çoğunlukla geri dönüşümsüzdür ve ölüm ile sonuçlanmaktadır (House ve ark., 2008, Angus ve van der Poll 2013, Şen ve ark., 2013, Thomas 2014, Constable ve ark., 2016, Al-Khafaji ve Pinsky 2017).

Buzağllarda neonatal dönemde sepsis ve sepsisin, organ ve sistemler üzerine yapmış olduğu bozukluklar ve bunların teşhisine yönelik çalışmalar oldukça yetersizdir. Sepsis olgularında tedavideki başarı; yıkımlanmaların geri dönüşümsüz olmadan erken teşhisine ve tedavisine başlanmasına dayanır. Neonatal buzağılarda sepsisin hematolojik ve biyokimyasal parametreler ile birlikte organ veya sistemler üzerine etkisi ile ilgili çalı̧malar son derece yetersizdir. Bu çalş̧mada sepsisli neonatal buzağılarda hematolojik ve biyokimyasal parametrelerdeki değişimlerin araştırılması amaçlanmıştur. Ayrıca elde edilen veriler ışığında gelişen organ veya sistem bozukluklarının belirlenmesi de hedeflenmiştir.

\section{Gereç ve Yöntem}

\section{Hayvan Materyali}

$\mathrm{Bu}$ araştırmanın materyalini Burdur Mehmet Akif Ersoy Üniversitesi Veteriner Fakültesi İç Hastalıkları Büyük Hayvan Kliniğine getirilen yaşları 1-30 gün arasında değişen 20 sepsis şüpheli (Deneme grubu) ve bir süt sığırı işletmesinde bulunan ve aynı yaş grubunda, klinik olarak sağlıklı 10 buzağı (kontrol grubu) oluşturmaktadır.

Neonatal buzağılarda sepsis kriterleri tam olarak belirlenemediğinden, çalışmada kullanılan sepsis kriterleri buzağılarda yapılan çalışmalardan uygun şekilde modifiye edilerek oluşturulmuştur (Fecteau ve ark., 1997, Şen ve ark., 2013, Başoğlu ve ark., 2014, Cho ve Yoon, 2014, Constable ve ark., 2016). Çalışmada sepsisli buzağıların belirlenmesinde aşağıdaki sepsis kriterleri kullanılmıştır (Tablo 1).

Tablo 1. Neonatal Buzağılarda Sepsis Kriterleri

\begin{tabular}{ll}
\hline Kriter & Sonuç \\
\hline Rektal 1s1 $\left({ }^{\circ} \mathbf{C}\right)$ & $>39,<36$ \\
Kalp frekans1 $(\mathbf{x} / \mathbf{d k})$ & $>160,<100$ \\
Solunum sayısı $(\mathbf{x} / \mathbf{d k})$ & $>45$ \\
$\mathrm{SpO}_{2}(\%)$ & $<90$ \\
$\mathrm{MAP}_{(\mathbf{m m H g})}$ & $<65$ \\
Total lökosit $(\mathbf{x} / \boldsymbol{\mu l})$ & $>12000,<4000$ \\
\hline
\end{tabular}

$\mathrm{SpO}_{2}$ : arteriyel kan oksijen saturasyonu, MAP: ortalama arteriyel kan basınc1. 


\section{Klinik Muayeneler}

Kliniğe getirilen ishalli buzağıların anemnez bilgileri alınarak rutin klinik muayeneleri yapıldı ve en az iki sepsis kriterine sahip olan buzağılar (deneme grubu) hayvan sahibinin onamı alınarak çalışmaya dahil edildi. Buzağıların rektal 1sı, kalp frekans1, solunum sayıs1, dehidrasyon durumu, emme refleksi, mukozaların durumu, çevreye ilgi, ayakta veya yatıyor oluşu ve dışkılama durumu gibi klinik bulgular belirlenerek kayıt altna alındı. Buzağılar monitörize edilerek (BM5vet Ltd. G. Kore) sistolik kan basınc1 (SKB), diyastolik kan basinc1 (DKB), ortalama arteriyel kan basinc1 (MAP) ve pulse oksimetre ile de oksijen saturasyonu $\left(\mathrm{SpO}_{2}\right)$ ölçüldü. Klinik bulgulara göre en az iki sepsis kriteri taşıyan, emme refleksi olan veya azalmış, ayakta ve dehidrasyon derecesi \%5$\% 6$ aralı̆̆ında olan buzağılar ayakta olan grup (orta derecede şiddetli sepsisli, $n=6$ ) olarak kabul edildi. Yatar pozisyonda olan, depresif, emme refleksi azalmış veya tamamen kaybolmuş, dehidrasyon derecesi \% $\%$ - \%10 civarında olan ve en az iki sepsis kriteri taşıyan buzağılar ise yatar pozisyonda olan grup (şiddetli derecede sepsisli, $n=14$ ) olarak kabul edildi.

\section{Laboratuvar Muayeneleri}

\section{Kan örneklerinin alınması}

Bütün gruplardan tedavi öncesi Vena jugularis'ten kan örnekleri $K_{3} E D T A ' l$ ve aktivatörlü jelli antikoagulansız tüplere alındı (BD vacutainer, INGIILTERE). K ${ }_{3}$ EDTA'lı kan örnekleri $15 \mathrm{dk}$ içinde hemogram ölçümü için, antikoagulansız kan örnekleri ise serum elde etmek için kullanıldı.

\section{Hemogram}

Sepsisli ve kontrol grubunda yer alan buzağılara ait

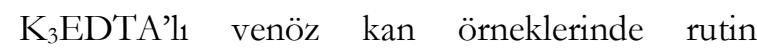
hemogram parametreleri tam kan sayım cihazı ile belirlendi (Abacus Junior Vet, Diatron MI Ltd. MACARISTAN).

\section{Biyokimyasal Parametrelerin Öıçümü}

Serum total protein (TP), albumin (ALB), total bilirubin (T.Bil), direkt bilirubin (D.Bil), kan üre nitrojen (BUN), kreatinin (KREA) düzeyleri ve laktat dehidrojenaz (LDH), aspartat alanin aminotransferaz (AST), gammaglutamyl transferaz (GGT), alkalin fosfataz (ALP) aktiviteleri fotometrik yöntemlerle (Abbott Architect Ci8200 Biyokimya cihazı, ABD) ölçüldü. İmmunoglobulin (Ig) düzeyleri her hayvan için belirlenen total protein değerinden albümin değerinin çıkarılması ile belirlenirken, indirekt bilirubin (İ.BİL) ise total bilirubinden direkt bilirubinin çıarılması ile hesaplandi.

\section{Istatistiksel Analiz}

Çalışma sonucunda elde edilen verilerin normal dağılımı Kolmogorov Smirnov testi ile belirlendi. Normal dağ 1 llım gösteren parametrelerden sepsisli ve kontrol gruplarına ait veriler arasındaki istatistiksel anlamlar bağımsız $\mathrm{t}$ test ile, ayakta duran, yatan sepsisli ve kontrol grubu buzağılara ait parametreler arasındaki farkliliklar ise One Way Anova (posthoc Duncan) ile değerlendirildi.

Çalışmada sepsisli buzağılarda analiz edilen parametrelerdeki bireysel artış veya azalışları belirlemek için her parametre için kesim noktası (cut-off) değeri oluşturuldu. Bunun için kontrol grubu buzağılardan elde edilen parametrelerin ortalama değerlerine o parametrenin 2 standart sapması eklenerek artıslar veya çkarılarak düşüşler için kesim noktası (cut-off) oluşturuldu. Her parametre için belirlenen kesim noktasının üzerinde olan değerler o hayvan için artış, altında olan değerler ise yine o hayvan için düşüş olarak kabul edildi (Knowles ve ark., 2000, Sing ve ark., 2006, Rastowici ve ark., 2011).

\section{Bulgular}

Sepsisli buzağıların yapılan klinik muayenesinde rektal 1silarının $\left(37.32 \pm 1.49{ }^{\circ} \mathrm{C}\right)$ kontrol grubuna göre daha düşük olduğu belirlendi $(\mathrm{p}<0.001$, Tablo 2). Sepsisli grupta yer alan $4(\% 20)$ hayvanin rektal 1sılarının $36^{\circ} \mathrm{C}$ 'nin altında olduğu yani hipotermik olduğu (en düşük $33.7^{\circ} \mathrm{C}$ ) belirlendi. Sepsisli buzağılardan 2 tanesi hipertermik (en yüksek $40^{\circ} \mathrm{C}$ ) $\left(>39^{\circ} \mathrm{C}\right)$ iken geri kalan 14 buzağının ise rektal 1sılarının sepsis kriterleri dışında olduğu $\left(<39^{\circ} \mathrm{C}\right.$, $\mathrm{T}>36^{\circ} \mathrm{C}$ ) saptandı (Tablo 2). Sepsisli buzağıların 
kalp frekansları ile kontrol grubu buzağıların değerleri karşılaştırıldığında bazı hayvanlarda artışın bazı hayvanlarda ise düşüşün olması nedeniyle istatistiksel olarak anlamlı bir farkın olmadığ1 görüldü. Bununla birlikte sepsisli grupta yer alan 5 (\%25) hayvanın kalp atım sayısının (atım<100/dk) düşük olduğu ve en düşük 72 atım/dk olduğu saptanmıştır (Tablo 2). Sepsisli buzağılarda solunum sayısının $(47.8 \pm 17.83 / \mathrm{dk})$ kontrol grubu değerlerine göre anlamlı bir şekilde arttğı saptanmıştır $(\mathrm{p}<0.001)$. Sepsisli grupta yer alan buzağılardan $10(\% 50)$ hayvanın solunum sayısının artmış $(>45 / \mathrm{dk})$ olduğu ve en yüksek değerin 92/dk olduğu belirlenmiştir (Tablo 2).

Sepsisli buzağıların ortalama $\mathrm{SpO}_{2}$ değerinin $\% 86.25 \pm 7.95$ olduğu ve kontrol grubu değerleri ile karşılaştırıldığında anlamlı düzeyde düşük olduğu belirlenmiştir $(\mathrm{p}<0.001)$. Sepsisli buzağılarda $\mathrm{SpO}_{2}$ değerlerinin bazı hayvanlarda düştügü bazı hayvanlarda ise normal seviyelerde olduğu belirlenmiştir. $\mathrm{Bu}$ hayvanlardan 13 (\%65) tanesinde $\mathrm{SpO}_{2}$ 'nin $<\% 90$ olduğu ve en düşük değerin ise \%71 olduğu saptanmıştır (Tablo 2). Çalışmada yer alan sepsisli buzağıların SKB, DKB ve MAP değerlerinin kontrol grubundan faklı olmadığ1 saptanmış olup en düşük ve en yüksek değerleri arasında ise büyük farkll1ıkların olduğu görülmüştür. Ayrıca sepsisli buzağılardan 3 (\%15) tanesinde MAP'ın < 65 mmHg olduğu ve en düşük değerin ise $53 \mathrm{mmHg}$ olduğu belirlenmiştir (Tablo 2). Çalışmada yatan ve ayakta duran sepsisli buzağıların klinik bulguları değerlendirildiğinde, yatan sepsisli buzağllarda dehidrasyon derecesinin $(\% 8.33 \pm 1.49)$ ayakta duran buzağılardan $(\% 5.5 \pm 0.54)$ daha yüksek olduğu $\quad(\mathrm{p}<0.01)$ saptanırken yatan buzağıların rektal ısılarının $\left(36.7 \pm 1.14{ }^{\circ} \mathrm{C}\right)$ ise ayakta duranlara $\left(38.86 \pm 0.88^{\circ} \mathrm{C}\right)$ göre daha düşük olduğu $(\mathrm{p}<0.01)$ belirlenmiştir. Yatan ile ayakta duran sepsisli buzağıların, solunum sayısı, MAP ve $\mathrm{SpO}_{2}$ değerleri arasında anlamlı bir fark bulunmamasına rağmen, bu parametrelerin yatan hayvanlarda daha çok sayıda hayvanda değiştiği belirlenmiştir. Çalışmada yatan sepsisli grupta hayvanların solunum sayısı artış1 \%57'sinde, $\mathrm{SpO}_{2}$ düşüşü \%78'inde ve MAP düşüşü ise $\% 21$ inde belirlenmiştir. Ayakta duran buzağılarda ise solunum sayış artışı hayvanların \%33'ünde, $\mathrm{SpO}_{2}$ düşüşü \%33'ünde belirlenirken, MAP değerleri ayakta duran tüm sepsisli buzağılarda kontrol grubunun değerlerine yakın olarak elde edilmiştir.

Tablo 2. Sepsisli ve kontrol grubu buzağılların klinik bulguların karşılaştırılması, (Ortalama

\begin{tabular}{lllll}
\hline Parametreler & $\begin{array}{l}\text { Kontrol Grubu } \\
(\mathrm{n}: 10)\end{array}$ & $\begin{array}{l}\text { Sepsisli Grup } \\
(\mathrm{n}: 20)\end{array}$ & $\begin{array}{l}\text { En düşük - } \\
\text { En yüksek }\end{array}$ & p değeri \\
\hline Yaş (gün) & $11.5 \pm 6.34$ & $10.3 \pm 7.86$ & $1-30$ & \\
Rektal ıs1 ( $\left.{ }^{\circ} \mathbf{C}\right)$ & $39.7 \pm 0.37$ & $37.32 \pm 1.49$ & $33.6-40$ & 0.0001 \\
Solunum sayıs1 (x/dk) & $36.9 \pm 4.67$ & $47.8 \pm 17.83$ & $22-92$ & 0.017 \\
Kalp frekans1 (x/dk) & $124.4 \pm 21.11$ & $110.52 \pm 23.14$ & $72-156$ & 0.120 \\
SKB (mmHg) & $149 \pm 14.51$ & $144.44 \pm 34.43$ & $77-202$ & 0.629 \\
DKB (mmHg) & $92 \pm 19.68$ & $97.61 \pm 33.6$ & $41-181$ & 0.582 \\
MAP (mmHg) & $111 \pm 16.06$ & $113.22 \pm 32.56$ & $53-137.66$ & 0.811 \\
SpO $(\%)$ & $93.3 \pm 3.4$ & $86.25 \pm 7.95$ & $71-99$ & 0.002 \\
Dehidrasyon (\%) & 0 & $7.4 \pm 1.78$ & $5-10$ & \\
\hline
\end{tabular}

SKB: sistolik kan basınc1, DKB: diyastolik kan basınc1, MAP: ortalama arteriyel kan basinc1, $\mathrm{SpO}_{2}$ : sature arteriyel oksijen 


\section{Hemogram Bulguları}

Sepsisli buzağıların WBC $(\mathrm{p}<0.01), \quad$ MID $(p<0.001)$, GRA $(p<0.01), \%$ MID $(p<0.001)$, MCV ( $p<0.01), \operatorname{MCH}(p<0.001), \operatorname{MCHC}(p<0.01)$ değerlerinin kontrol grubuna göre istatistiksel olarak anlamlı düzeylerde yüksek olduğu belirlenmiştir (Tablo 3). Sepsisli buzağ1lardan 14 $(\% 70)$ tanesinde lökositoz $(>12000 / \mu \mathrm{l})$ belirlenirken 2 (\%10) buzağıda lökopeni $(<4000 / \mu \mathrm{l})$ belirlenmiştir.

Çalışmada ayakta duran sepsisli buzağıların WBC değerlerinin $\left(22.14 \pm 7.79 \times 10^{9} / \mathrm{L}\right)$ yatan grubun değerlerinden $\left(14.89 \pm 9.35 \times 10^{9} / \mathrm{L}\right)$ daha yüksek olduğu saptanmıştır $(\mathrm{p}<0.01)$. Ayakta ve yatan pozisyonda duran sepsisli buzağıların diğer hematolojik parametrelerinin birbirinden istatistiksel olarak farklı olmadığı belirlenmiştir.

Tablo 3. Sepsisli ve kontrol grubu buzağıların hemogram bulguları (Ortalama \pm Standart sapma)

\begin{tabular}{lllll}
\hline Parametreler & $\begin{array}{l}\text { Kontrol Grubu } \\
\text { (n:10) }\end{array}$ & $\begin{array}{l}\text { Sepsisli Grup } \\
\text { (n:20) }\end{array}$ & $\begin{array}{l}\text { En düşük - } \\
\text { En yüksek }\end{array}$ & p değeri \\
\hline WBC (x109/L) & $10.35 \pm 1.09$ & $17.56 \pm 9.82$ & $1.32-38.96$ & 0.004 \\
LYM (x109/L) & $6.02 \pm 1.45$ & $5.93 \pm 2.44$ & $1.3-9.98$ & 0.0902 \\
MID (x109/L) & $0.13 \pm 0.12$ & $0.80 \pm 0.49$ & $0.02-1.81$ & 0.0001 \\
GRA (x109/L) & $4.19 \pm 1.41$ & $10.2 \pm 8.27$ & $0.67-30.28$ & 0.005 \\
LYM (\%) & $58.34 \pm 14.10$ & $40.63 \pm 15.57$ & $19.9-89.4$ & 0.005 \\
MID (\%) & $1.09 \pm 0.42$ & $5.41 \pm 2.68$ & $0.6-9.8$ & 0.0001 \\
GRA (\%) & $40.58 \pm 13.83$ & $51.2 \pm 19.96$ & $6.9-77.7$ & 0.102 \\
RBC (x10 $\%$ /L) & $8.19 \pm 1.08$ & $8.12 \pm 2.0$ & $4.71-12.36$ & 0.906 \\
HGB (g/d) & $8.14 \pm 1.08$ & $9.3 \pm 2.39$ & $4.7-132.7$ & 0.079 \\
HCT (\%) & $28.01 \pm 3.45$ & $30.55 \pm 7.5$ & $13.45-42.37$ & 0.216 \\
MCV (fl) & $34.2 \pm 2.65$ & $37.92 \pm 3.70$ & $29-46$ & 0.004 \\
MCH (pg) & $9.96 \pm 0.59$ & $11.49 \pm 0.97$ & $9.4-13.2$ & 0.0001 \\
MCHC (g/dl) & $29.06 \pm 1.16$ & $30.44 \pm 1.76$ & $27.8-34.9$ & 0.017 \\
RDWc (\%) & $27.54 \pm 2.17$ & $26.7 \pm 3.72$ & $21.3-35.4$ & 0.443 \\
PLT (x109/L) & $559.4 \pm 157.98$ & $512.45 \pm 182.74$ & $70-1163$ & 0.475 \\
\hline
\end{tabular}

WBC: total lökosit, LYM: lenfosit, MID: monosit, GRA: granulosit, RBC: eritrosit, HGB: hemoglobin, HCT: hemotokrit, MCV: alyuvar ortalama çapı, MCH: ortalama eritrosit hemoglobini, MCHC: ortalama eritrosit hemoglobin konsantrasyonu, RDWc: eritrosit dağılım hacmi, PLT: trombosit 


\section{Biyokimyasal Bulgular}

Sepsisli buzağıların T.BİL $(\mathrm{p}<0.02)$, D.BİL $(p<0.001), \quad$ ÜRE $(p<0.001), \quad$ KREA $(p<0.001)$, AST $(p<0.01)$ ve LDH $(p<0.001)$ değerlerinde kontrol grubuna göre anlaml düzeyde artışlar belirlenirken; TP $(p<0.01)$, ALB $(p<0.001), \operatorname{Ig}(p<0.001)$ değerlerinde ise kontrol grubuna göre anlamlı düzeyde düşüşler belirlenmiştir (Tablo 4). Sepsisli buzağılardan 14 $(\% 70)$ tanesinin TP değerinin kesim noktası olan
$5.71 \mathrm{~g} / \mathrm{dl}$ 'nin altında (\%50'si $<2 \mathrm{~g} / \mathrm{dl})$ olduğu ve 11 tanesinin (\%55) Ig değerinin kesim noktası olan $3.26 \mathrm{~g} / \mathrm{L}$ 'nin altında olduğu belirlenmiştir. Ayrıca, hesaplanan kesim noktalanı dikkate alındığında 11 (\%55) sepsisli buzağıda ALB düzeyi düşük olarak belirlenirken, yine T.BİL, D.BİL, İ.BİL, ÜRE, KREA, AST, LDH ve ALP değerlerinde sırası ile 13 (\%65), 12 (\%60), 8 (\%40), 14 (\%70), 18 (\%83), $14(\% 70), 14(\% 70)$ ve $6(\% 30)$ sepsisli buzağıda yükselişler saptanmıştır.

Tablo 4. Sepsisli ve sağlıklı buzağıların biyokimyasal bulguları (Ortalama \pm Standart sapma).

\begin{tabular}{lllll}
\hline Parametreler & Kontrol Grubu & Sepsisli Grup & En düşük- & p değeri \\
& $(\mathrm{n}: 10)$ & $\mathbf{( n : 2 0 )}$ & En yüksek & \\
\hline TP (g/dl) & $6.81 \pm 0.55$ & $5 \pm 1.55$ & $2.6-9.5$ & 0.0001 \\
ALB (g/dl) & $2.33 \pm 0.21$ & $1.83 \pm 0.38$ & $1-2.5$ & 0.0001 \\
Ig (g/dl) & $4.48 \pm 0.61$ & $3.16 \pm 1.24$ & $1.4-7.1$ & 0.001 \\
T.BİL (mg/dl) & $0.15 \pm 0.02$ & $0.48 \pm 0.57$ & $0.08-2.06$ & 0.02 \\
D.BİL (mg/dl) & $0.07 \pm 0.03$ & $0.17 \pm 0.09$ & $0.03-0.43$ & 0.0001 \\
İ.BİL (mg/dl) & $0.08 \pm 0.02$ & $0.3 \pm 0.51$ & $0.01-1.79$ & 0.072 \\
ÜRE (mg/dl) & $26.21 \pm 5.13$ & $97.85 \pm 76.42$ & $18-256$ & 0.0001 \\
KREA (mg/dl) & $0.58 \pm 0.04$ & $2.27 \pm 1.85$ & $0.27-7.24$ & 0.001 \\
GGT (U/L) & $299.2 \pm 199.2$ & $278.8 \pm 358.36$ & $27-1543$ & 0.843 \\
AST (U/L) & $31.3 \pm 7.11$ & $114.65 \pm 103.78$ & $23-433$ & 0.002 \\
LDH (U/L) & $508.18 \pm 77.29$ & $1002.5 \pm 518.61$ & $413-1995$ & 0.0001 \\
ALP (U/L) & $190.2 \pm 45.48$ & $299.8 \pm 270.44$ & $59-1213$ & 0.092
\end{tabular}

TP: total protein, ALB: albumin, T.BIL: total bilirubin, D.BİL: direkt bilirubin, ÜRE: kan üre, CREA: kreatinin, LDH: laktat dehidrojenaz, AST: Aspartat alanine animotransferaz, GGT: Gammaglutamyl transferase, ALP: Alkaline fosfataz, Ig: Immunoglobulin.

Ayakta duran ve yatar durumda olan sepsisli buzağıların analiz edilen biyokimyasal parametrelerinin kendi aralarında anlaml düzeyde farklı olmadığ1 belirlenmiştir. Bununla birlikte analiz edilen biyokimyasal parametreler için oluşturulan kesim noktası (cut-off) değerleri dikkate alındığında yatan durumda olan sepsisli grupta ayakta olanlara göre daha çok sayıda hayvanda bu parametrelerde değişim olduğu belirlenmiştir. Ayakta duran sepsisli buzağıların 
TP, ALB, Ig değerlerinde sirası ile $3(\% 50), 3$ (\%50), 2 (\%33) buzağıda düşüşler belirlenirken, yatar durumda olan sepsisli grupta ise TP, ALB ve Ig değerlerinde sırası ile $11(\% 78), 8$ (\%57) ve 9 (\%64) buzağıda düşüşler saptanmıştır. Ayrıca ayakta duran sepsisli buzağıların T.BILL 5 (\%83), D.BİL 3 (\%50), İ.BİL 4 (\%66), ÜRE 5 (\%83), KREA 5 (\%83), AST $3(\% 50)$, LDH 3 (\%50) ve ALP değerlerinde 1 (\%16) buzağıda artışlar saptanmıştır. Buna karşın yatar durumda olan sepsisli buzağıların T.BİL, D.BİL, İ.BİL, ÜRE, KREA, AST, LDH ve ALP değerlerinde sirası 8 (\%57), 9 (\%64), 5 (\%35), 11 (\%78), 13 (\%93), 12 $(\% 85), 11(\% 78)$ ve $5(\% 35)$ buzağıda artışlar belirlenmiştir.

\section{Tartışma}

Buzağılarda neonatal dönem çok kritik bir dönem olup bu dönem buzağılar için fizyolojik fonksiyonların geliştiği ve doğum sonrası hayata adapte olduğu bir dönemdir. Buzağıların immun sistemleri henüz gelişmediği için enfeksiyöz etkenlere karşı korunmasız olarak doğarlar ve bu dönemde bakteriyel, viral ve paraziter patojenlere daha kolay maruz kalıllar (House ve ark., 2008, Poulsen ve ark., 2010, Başoğlu ve ark., 2014, Smith, 2015, Bedenice ve ark., 2016, Constable ve ark., 2016). Buzağılarda neonatal dönemde gelişen hastalıklar arasında sindirim sistemi hastalıkları ve özelliklede neonatal ishaller önemli bir yer tutmaktadır (Fecteau ve ark, 2009, Pardon ve Depres, 2018, ). Gelişen enfeksiyon sonucu bakteriyemi veya viremi şekillenerek sistemik yang1ya yani sepsise neden olmaktadır. Sepsisin yeterince şiddetli ve uzun sürmesi durumunda da septik şok ve daha sonra da çoklu organ yetmezlikleri gelişmekte ve bu aşamadan sonra da genellikle ölüm ile sonlanmaktadır (Merx ve Weber, 2007, House ve ark., 2008, Fecteau ve ark., 2009, Angus ve van der Poll 2013, Şen ve ark., 2013, Cho ve Yoon 2014, Gasparavic ve ark., 2014, King ve ark, 2014, Osterbur ve ark., 2014, Thomas 2014, Bedenice 2016, Constable ve ark., 2016, Al-Khafaji ve Pinsky,2017, Pardon ve Depres, 2018,). Sepsis ilerledikçe organizmada gelişen hasar daha büyük olmakta bu durum tedaviyi güçleştirmekte hatta imkansız hale getirmektedir. $\mathrm{Bu}$ nedenle sepsiste komplikasyonların belirlenmesi, erken teşhis ve tedavi edilmesi hastanın yaşama şansını da arttırmaktadır. Bununla birlikte günümüzde hem insanlarda hem de hayvanlarda sepsis ve sonrasında gelişen komplikasyonlara bağlı ölüm oranları hala yüksek seyretmekte olup ciddi bir problem olarak önemini korumaktadır (Martin ve ark., 2003, Vincent ve ark., 2006, Osterbour ve ark., 2014). Sepsiste gelişen klinik bulguların değişken olması nedeniyle buzağılarda sepsis kriterlerini koymak oldukça güçtür (Fecteau ve ark., 1997, Lofstedt ve ark., 1999, Şen ve ark., 2013, Constable ve ark., 2016, Pardon ve Depres, 2018). Bu konuda yapılan çalışmalarda ön plana çıkan klinik sepsis kriterleri arasında dehidrasyon, depresyon, skleral damarlarda dolgunluk, emme refleksi kayb1, anormal rektal 1s1, taşikardi, taşipne, hipovolemi, hipotansiyon, düşük $\% \mathrm{SPO}_{2}$ ve MAP ve lokal enfeksiyon varllğı gibi bulgular yer almaktadır (Lofstedt ve ark., 1999, Pardon ve Depres, 2018). Bununla birlikte Fecteau ve ark (1997) tarafindan sepsisli buzağılarda yapılan bir çalışmada rektal 1sı, solunum sayısı ve kalp frekansı normal bulunurken bir başka çalş̧mada ise buzağılarda hipotermi ve taşipne rapor edilmiştir (Lofstedt ve ark., 1999).

Yapılan mevcut çalışmada rektal 1s1, mukozalar, genel durum, emme refleksi, dehidrasyon, kalp frekans1 ve solunum sayısı dikkate alındığında sepsisli buzağılarda saptanan semptomların oldukça değişken olduğu görülmektedir (Tablo 2). Buzağıların bir kısmında klinik semptomlar daha hafif seyrederken bir kısmında daha şiddetli seyrettiği belirlenmiştir. Bu hayvanların bazılarında depresyon, yerde yatma, emme refleksinde azalma veya kaybolma, iştahsızlık, mukoz membranlarda hiperemi veya solgunluk, hipotermi veya hipertermi, taşikardi, solunum sayısında artış ve $\% 5$ 'den $\% 10$ 'a kadar değişen dehidrasyon derecesi belirlenmiştir (Tablo 2). Sepsisli buzağıların $\% \mathrm{SpO}_{2}$ değerleri ve rektal ssıları kontrol grubuna göre önemli derecede düşük bulunmuş olup, bu bulgular sepsisli buzağılarda rapor edildiği gibi solunumun sayısının artışı ile birlikte akciğerlerin vital kapasitesinin düştüğünü göstermektedir (Lofstedt ve ark., 1999, Poulsen ve ark., 2010, 
McGirk, 2011, Bednarski ve ark., 2015, , Smith 2015, Bedenici 2016, Constable ve ark., 2016, Pardon ve Depres, 2018). Yapılan çalışmada sepsisli buzağıların MAP, SKB ve DKB değerlerinin ise kontrol grubundan istatistiksel olarak farklı olmadığı belirlenmiştir (Tablo 2). Çalışmada hesaplanan kesim noktası (cut-off) değerleri dikkate alındığında buzağıların bazılarının değerlerinde azalış, bazılarında artış bazılarında ise normal değerlerin belirlendiği görülmüştür. Elde edilen bireysel düzeyde farklı sonuçların sepsisin etiyolojisi, şiddet ve sürecine bağlı olarak oluştuğu düşünülmektedir. Ayrıca bazı sepsisli buzağılarda belirlenen $\% \mathrm{SpO}_{2}$ düzeyinde ve MAP değerindeki düşüşlerin muhtemel nedenleri arasında da dehidrasyona bağlı gelişmiş olan hipovolemi, hipotansiyon, hipoksi ve daha önceki çalışmalarda belirlenmiş olan kalp fonksiyonlarının baskılanmas1 da etkili olabilir (Lofstedt ve ark., 1999, Poulsen ve ark., 2010, McGirk, 2011, Bednarski ve ark., 2015, Smith 2015, Bedenici 2016, Constable ve ark., 2016, Pardon ve Depres, 2018). Çalsşmada ayrıca yatan (şiddetli derecede) sepsisli buzağılarda ayakta duran (orta derecede) sepsisli buzağılara göre daha fazla sayıda hayvanda emme refleksinin kaybolduğu, dehidrasyon derecesinin daha yüksek, buna karşın rektal ısının ise daha düşük olduğu tespit edilmiştir.

Sonuç olarak yatar pozisyonda olan sepsisli buzağılarda hastalığın ayakta olan sepsisli buzağılara göre klinik olarak daha şiddetli seyrettiği söylenebilir. Bununla birlikte sepsisli buzağıların neonatal dönemde olmakla birlikte yaşlarının da 1 gün ile 30 gün arasında değiştiği saptanmış ve bu çalısmada sepsisin etiyolojisi belirlenmemiştir. Bu nedenle klinik semptomlardaki farklilikların çalışmaya dahil edilen buzağıların farklı hastalık evrelerinde, farklı yaş gruplarında olmasının yanında sepsise neden olan etiyolojinin farklılığından da kaynaklanabileceği kanaati de oluşmuştur.

Neonatal dönemde buzağılarda yapilan çalışmalarda \%HTC, HGB ve RBC değerlerinin buzağılarda doğumdan hemen sonra kısa sürede normale dönen artışlar gösterdiği, LYM, MCH, MCHC, MID değerlerinde değişimlerin olmadığ buna karşın nötrofil ve WBC değerlerinin ise doğum sonrası 6 ile 20 gün aralığında hafif artışlar gösterdiği saptanmıştır. Buzağıların doğum sonrası MCV değerinde doğumdan 13 gün sonra hafif düşüşler saptanırken PLT değerlerinde 6. günden itibaren artışlar saptanmıştır. Bununla birlikte buzağıların kolostrum almasının hematolojik değerlerde değişime neden olmadığı ortaya konulmuştur (Knowles ve ark., 2000, Jezek, 2007). Sepsisli buzağılarda yapılan çalı̧̧malarda lökositosiz veya lökopeni, lenfopeni, nötrofili veya nötropeni, trombositopeni saptanırken, HBG ve RBC değerlerinde normal veya düşük değerler ve ishalli olgularda \%HTC değerde artıslar saptanmıştır. Ancak yapılan çalışmalarda bu parametrelerin sepsisin etiyoloji ve şiddetine bağlı olarak değişkenlik gösterebileceği vurgulanmıştır (Lofstedt ve ark., 1999, Pardon ve Depres, 2018). Buna karşın sepsisli buzağılarda MCH, MCHC ve MCV değerlerinde değişimin olmadığ belirlenmiştir (Poulsen ve ark., 2010, McGirk, 2011, Singh ve ark., 2014, Brar ve ark., 2015, Smith 2015, Bedenici 2016, Constable ve ark., 2016, Kumar ve ark., 2018, Pardon ve Depres, 2018, Yıldız ve ark., 2018). Mevcut bu çalş̧mada ise sepsisli buzağıların WBC $(\mathrm{p}<0,01), \quad$ MID $(\mathrm{p}<0,001)$, GRA $(\mathrm{p}<0,01), \%$ MID $(\mathrm{p}<0,001)$, $\operatorname{MCV}(\mathrm{p}<0,01), \operatorname{MCH}(\mathrm{p}<0,001), \operatorname{MCHC}(\mathrm{p}<0,01)$ değerlerinin kontrol grubu buzağıların değerlerine göre anlamlı düzeylerde arttı̆̆ belirlenmiştir (Tablo 3). Sepsisli buzağılarda MCV, MCH ve MCHC, WBC, GRA değerlerinde görülen artısın muhtemel nedeni ise daha önceki çalışmalarda belirtildiği gibi organizmanın enfeksiyöz ajanlara karşı savunma mekanizması gereği artşstan ve dehidrasyona bağlı hemokonsantrasyondan kaynaklandığ1 düşünülmektedir (Santos ve ark., 2002, Asati ve ark., 2008, Brar, 2015).

Mevcut çalışmada sepsisli buzağılardan elde edilen hemogram bulgularında bireysel farkliliklar belirlenmiş olup bu muhtemelen rapor edildiği gibi buzağılardaki yaş farkı, sepsisin etiyoloji, süreç ve şiddetinden kaynaklanmaktadır (Fecteau ve ark., 1997, Lofstedt ve ark., 1999, Pardon ve Depres, 2018). Çalışmada ayakta olan buzağılarda yatanlara göre belirlenen daha yüksek WBC değeri $(\mathrm{p}<0.01)$ bu hayvanlarda mevcut enfeksiyona karşı daha 
güçlü bir savunmanın varlığının bir göstergesi olabilir.

Buzağılarda yapılan çalışmalar bazı biyokimyasal parametrelerin neonatal dönemde yaşa ve kolostrum alıp almamasına göre değişkenlik gösterdiğini ortaya koymuştur (Kurz ve Willet, 1991, Egli ve Blum, 1998, Knowles ve ark., 2000, Lassen, 2004, Maden ve ark., 2004, Mahri ve ark., 2007, Jezek ve ark., 2006, Jezek 2007, Klinkon ve Jezek, 2012, Pekcan ve ark., 2013, Brar ve ark., 2014, Tothova ve ark., 2016, Aydoğdu ve Güzelbektaş, 2018). Kolostrum almış buzağıllarda ilk günlerde serum TP, Ig, AST, GGT, ALP ve LDH seviyeleri yükseldiği daha sonra düşmeye başladığı belirlenmiştir (Kurz ve Willet, 1991, Tyler ve ark., 1998, Knowles ve ark., 2000, Muri ve ark 2005, Jezek ve ark. 2006, Jezek 2007, Mahri ve ark., 2007, Pekcan ve ark., 2013, Tothova ve ark., 2016). $\mathrm{Bu}$ nedenle yapilacak biyokimyasal değerlendirmelerde buzağının yaşı ve kolostrum alıp almadığına dikkat edilmesi önerilmektedir (Knowles ve ark., 2000, Muri ve ark., 2005, Jezek ve ark., 2006, Jezek 2007, Mahri ve ark., 2007, Klinkon ve Jezek, 2012).

Serum üre konsantrasyonu alınan besine bağlı olup kreatinin ile birlikte böbrek hastalıklarını belirlenmesinde kullanılmaktadır. Buzağılarda serum üre düzeyinin artması protein yıkımlanmasının artmasını göstermekte olup aynı zamanda dehidrasyona bağlı olarak da artmaktadır (Maach ve ark., 1992, Kaneko, 1997, Santos ve ark., 2002, Kaur ve ark., 2006, Himanshu, 2010, Klinkon ve Jezek, 2012). Kreatinin ise kaslarda sentezlenmekte ve idrarla atılmaktadır. Serumdaki konsantrasyonu beslenmeye bağlı değildir. Glomerular filtrasyonun ciddi boyutta bozulduğu böbrek hastalıklarında serum düzeyi artmaktadır (Kaneko, 1997). İshalli neonatal buzağılarda yapılan çalş̧malarda ise serum üre ve kreatinin seviyelerinde artışlar saptanmıştır (Santos ve ark., 2002, Himanshu, 2010, Başer ve Civelek, 2013, Singh ve ark., 2014). Yapılan mevcut çalş̧mada serum ÜRE $(p<0.001)$ ve KREA $(p<0.001)$ seviyeleri sepsisli buzağılarda kontrol grubuna göre anlamlı düzeyde yüksek bulunmuştur (Tablo 4). Yapılan çalş̧mada sepsisli buzağılarda aynı zamanda $\%-5-\% 10$ aralığında dehidrasyon belirlenmiş olup bu değerlerdeki artış dehidrasyonda gelişen hipovolemiye bağlı olarak böbreklere yeterince kan akışının sağlanamaması ve bunun sonucunda üre ve kreatinin kandan yeterli düzeyde uzaklaştırılamaması olduğu düşünülmektedir. Çalışmada elde edilen ÜRE ve KREA düzeylerindeki artışlar sepsisli neonatal buzağılarda böbrek fonksiyonlarının negatif yönde etkilendiğini ortaya koymakta olup bu durum sepsis olgularında tanı, tedavi ve prognoz yönünden göz önünde bulundurulmalıdır.

T.BİL eritrositlerin dalak, karaciğer ve kemik iliğinde yıkımlanması sonucu hem molekülünden üretilir. Plazmada indirekt bilirubin olarak bulunur ve albümine bağlanarak karaciğere taşınır. Karaciğerde konjuge olarak direk bilirubin halinde bağırsaklara taşınır (Kaneko, 1997, Klinkon ve Jezek, 2012). Serumda T.BİL artışı safra durgunluğu, karaciğer hastalıklanı ve hemolitik anemilerde görülür. İndirekt bilirubin pre-hepatik olarak eritrosit yıkımlanması sonucu ve karaciğer kökenli olarak bilirubinin konjuge edilememesi sonucu artarken, direkt bilirubin ise karaciğer hastalıkları, safra durgunluğu ve safranın ince bağırsaklara akışının engellendiği durumlarda artmaktadır (Kaneko, 1997, Kaneko, 2008, Klinkon ve Jezek, 2012). Yeni doğanlarda fötal hemoglobin yıkımlanmasına bağlı olarak T.BİL seviyesinin yükseldiği ve bunun 6-14 gün içinde normal seviyeye döndügü rapor edilmiştir (Kurz ve Willet, 1991, Kaneko, 1997, Tennant, 1997, Mohri ve ark., 2007, Klinkon ve Jezek, 2012). İshalli buzağılarda yapılan birçok çalışmada serum T.BİL ve D.BİL seviyelerinde artş belirlenmiş olup bu artış karaciğer ve safra kanalı yıkımlanmalarına bağlanmıştır (Santos ve ark., 2002, Bozukluhan ve ark., 2017). Yapilan mevcut çalışmada ise sepsisli neonatal buzağıların T.BİL $(p<0.01)$ ve D.BIL $(p<0.001)$ düzeylerinde önemli artışlar belirlenmiştir (Tablo 4). Sepsisli buzağılarda T.BİL'deki artışların her ne kadar fötal hemoglobin yıkımlanmasından kaynaklanabileceği mümkünse de özellikle D.BİL'de de artşların olması ve bu artışların kontrol grubundan daha yüksek olması bunun kaynağının aynı zamanda 
karaciğer veya safra durgunluğunun da olabileceği ihtimali ortaya çıkmaktadır.

Buzağılarda TP seviyesinin kolostrum alınması ile birlikte arttı̆̆1 saptanmış olup Ig ile TP'nin buzağıllarda ilk gün ölçülmesi buzağının yeterli düzeyde kolostrum alıp almadığının belirlenmesinde kullanılabileceği ileri sürülmektedir (Tyler ve ark., 1998, Muri ve ark 2005, Jezek ve ark., 2006, Klinkon ve Jezek, 2012, Tothova ve ark., 2016). Buzağllarda Ig seviyelerinin ise kolostrum alınması ile birlikte ilk 2 gün artış gösterdiği daha sonra Ig'lerin bağırsaklarda yıkımlanması ile birlikte düşüşe geçtiği ve buzağının daha az düzeyde Ig sentezlemesi ile de bu düşüşün bir süre daha devam ettiği belirlenmiştir (Klinkon ve Jezek, 2012, Brar ve ark., 2014). İshalli neonatal buzağılarda yapılan çalışmalarda ise TP ve Ig düzeylerinin azalışı yetersiz kolostrum alınmasına, artışı ise dehidrasyona bağlanmıştır (Santos ve ark. 2002, Asati ve ark., 2008). Buzağılarda pasif immun transfer yetmezliğinin varllğı, Ig düzeyinin düşüklüğü, toksik nötrofil artısı ve kreatinin düzeyinin yüksekliği dominant sepsis bulgular olarak kabul edilirken, \%HCT artısı, TP düşüşü ve $\mathrm{PaCO}_{2}$ artışı veya $\mathrm{PaO}_{2}$ düzeyindeki düşüşler gibi parametrelerin ise değişken sepsis parametreleri olduğu öne sürülmektedir (Lofstedt ve ark., 1999, Pardon ve Depres, 2018). Yapilan mevcut çalışmada ise sepsisli buzağıların TP $(\mathrm{p}<0.01)$ ve Ig $(p<0.001)$ değerlerinde kontrol grubuna göre anlamlı düşüşler belirlenmiştir. (Tablo 4). Bu bulgulara ek olarak ayrıca sepsisli buzağılardan $\% 50$ 'sinin TP değerinin $2 \mathrm{~g} / \mathrm{dl}$ 'nin altnda ve $\% 20$ 'sininin ise $\operatorname{Ig}$ değerinin $20 \mathrm{~g} / \mathrm{L}$ 'nin altunda olduğu belirlenmiştir. Sepsis şüpheli buzağılarda dehidrasyona rağmen TP ve Ig değerlerinde düşüşlerin olması aynı zamanda bu buzağıların yetersiz düzeyde kolostrum aldığını göstermektedir. Ayrıca sepsisin gelişmesi ve buzağıların çoğunda enterit gibi enfeksiyon tablosunun da olması bu hayvanlarda pasif immun transfer yetmezliğinin olduğunu desteklemektedir.

Albumin karaciğerde sentezlenmekte olup serum konsantrasyonu karaciğerin gelişmişliği ve fonksiyon yeteneğine bağlıdır. Buzağılarda yapılan bazı çalışmalarda ALB seviyesinin doğumdan sonra kısa süreli arttığ1 (Knowles ve ark., 2000, Jezek ve ark., 2006, Kaur ve ark., 2006, Klinkon ve Jezek, 2012) bazı çalışmalarda ise önce kısa süreli düştüğü ve sonra artış gösterdiği (Santos ve ark., 2002, Lassen, 2004, Bednarski ve ark., 2015, Tothova ve ark, 2016) rapor edilmiştir. Buzağılarda uzun süren ishallerde ise hipoalbumineminin sebebi karaciğerin zarar görmesi ve artmış protein kullanımına bağlı olduğu ileri sürülmektedir (Knowles ve ark, 2000, Jezek, 2007). Bununla birlikte ishalli buzağılarda yapılan bir çalışmada ise ALB seviyesi dehidrasyon nedeniyle yüksek olduğu belirtilmiştir (Brar ve ark., 2014). Yapılan mevcut bu çalışmada ise serum ALB düzeyi sepsis şüpheli buzağlarda kontrol grubu değerlerine göre önemli düzeyde düşük $(p<0.001)$ bulunmuştur (Tablo 4). Bu düşüşün muhtemel nedeni sepsiste ortaya çıkan şiddetli yang1 ve dehidrasyona bağlı kan perfüzyonunun düşmesi sonucu karaciğer fonksiyonlarının da negatif yönde etkilenmesi olabilir.

AST birçok dokuda bulunmakta olup yumuşak doku yıkımlanmalarının iyi bir indikatörü olarak kabul edilmektedir. Bu enzim yoğun olarak kalp, iskelet kası ve karaciğer hücrelerinde stoplazma ve mitokondrilerde bulunur. $\mathrm{Bu}$ hücrelerde yıkımlanma veya membran geçirgenliğinin bozulduğu durumlarda serumdaki AST aktivitesi yükselmektedir (Kaneko, 1997, Kaneko 2008, Klinkon ve Jezek, 2012). ALP ise karaciğer, bağırsak ve kemik hücrelerinde bulunur ve hızlı büyüyen genç hayvanlarda kemik kökenli olarak yükseldiği bildirilmiştir (Kaneko, 1997). Serum ALP aktivitesinin gastroentestinal yang1 sonucu yıkımlanan bağırsak hücreleri, kolastasiz, osteoblastik ve osteoklastik aktivite artış, hepatoselüler sirkülasyonun bozulması, karaciğer y1kımlanması ve strese bağlı olarak arttığı ortaya konulmuştur (Kaneko, 1997, Klinkon ve Jezek, 2012). GGGT enzimi en yüksek olarak safra kanalı ve böbrek hücrelerinde bulunur. Serum GGT aktivitesinin yükselmesi safra durgunluğu ve safra kanalı y1kımlanmasına işarettir (Kaneko, 1997, Kaneko, 2008, Klinkon ve Jezek, 2012). Ayrica kolostrum alan buzağılarda hızla yükseldiği ve 20 gün içinde normal seviyeye indiği bildirilmektedir. 
Yeni doğanlarda serum GGT aktivitesinin düşük olması yetersiz kolostrum alınmasına işaret olarak kabul edilebilir (Klinkon ve Jezek, 2012). LDH enzimi hemen hemen bütün dokularda bulunmakta olup yoğun olarak karaciğer, kalp, böbrek, kas ve eritrositlerde bulunur. Serum düzeyindeki artıslar genellikle kas nekrozu, karaciğer hasarı ve hemolizlerde ortaya çıkmaktadır (Kaneko, 1997). İshalli neonatal buzağılarda yapılan çalışmalarda serum LDH düzeyinin arttığ1 ve bunun karaciğer paranşim y1kımlanmaları ve kalp hasalardan kaynaklanabileceği ileri sürülmüştür (Sobiech ve Kuleta, 2006). İshalli buzağılarda toksemiye bağlı karaciğer hasarı sonucu ALT AST ve GGT seviyelerinde artşs olabileceği ifade edilmektedir (Sobiech ve Kuleta, 2006, Başer ve Civelek, 2013, Bozukluhan ve ark., 2017, Aydoğdu ve Güzelbektaş, 2018). Yapılan mevcut çalışmada sepsisli buzağılarda AST $(\mathrm{p}<0.01)$ ve $\mathrm{LDH}$ $(p<0.001)$ değerlerinin kontrol grubuna göre önemli derecede yüksek olduğu belirlenmiştir. Sepsisli buzağglarda ALP düzeyi yüksek olmakla birlikte kontrol grubu ile aralarında anlamlı bir fark bulunamamıştur (Tablo 4). Sepsisli buzağıların GGT seviyeleri ise kontrol grubu değerlerine benzer olduğu saptanmıştır. Serum AST, LDH, GGT, ALP düzeyleri kolostrum almış buzağılarda yüksek olduğu rapor edilmiş olmakla birlikte kontrol grubu buzağılarında kolostrum aldığı ve aynı yaş grubu olduğu düşünüldüğünde bu çalışmada elde edilen farkların kolostrumdan kaynaklanmadığ1 bunun aksine başka bir kaynaktan köken aldığı düşünülebilir (Kurz ve Willet, 1991, Tyler ve ark., 1998, Knowles ve ark., 2000, Muri ve ark 2005, Jezek, ve ark., 2006, Jezek 2007, Mahri ve ark., 2007, Klinkon ve Jezek, 2012, Pekcan ve ark., 2013, Brar ve ark., 2014, Tothova ve ark., 2016). Dolayısı ile yapılan bu çalışmada AST düzeyindeki artış daha önceki çalısmalarda vurgulandığı gibi sepsis sonucu gelişen karaciğer yangısından kaynaklanabileceği buna karşın ALP'deki artışın ise gastrointestinal yangıya bağlı bağırsak hücrelerindeki yıkımlanma, safra kanalı yangis1, koleoastasiz, hepatoselüler kan sirkülasyonun bozulmasi ve stres sonucu olabileceği düşünülmektedir (Kaneko, 1997, Sobiech ve Kuleta, 2006, Klinkon ve Jezek, 2012,
Başer ve Civelek, 2013, Bozukluhan ve ark., 2017, Aydoğdu ve Güzelbektaş, 2018). Sepsisli buzağılarda GGT düzeyinin yükseliş göstermemesi ise TP ve Ig bulgularının da desteklediği gibi yetersiz kolostrum alınması ile ilişkilendirilebilir (Klinkon ve Jezek, 2012). Yapılan bu çalışmada, yatan (şiddetli derecede) sepsisli buzağılarda daha çok sayıda hayvanda biyokimyasal parametrelerde değişim olduğu saptanmış olup bu bulgular ışığında sepsisin şiddeti ile bu parametrelerdeki değişim arasında bir paralelliğin olduğu söylenebilir.

Sonuç olarak, elde edilen bulgular sepsisin neonatal buzağılarda klinik, hematolojik ve biyokimyasal parametrelerde önemli değişikliklere neden olduğunu göstermektedir. Sepsisin yatan hayvanlarda (şiddetli derecede sepsis) daha şiddetli seyrettiği ve daha şiddetli karaciğer ve böbrek fonksiyon bozukluklarına neden olduğu görülmektedir. Bununla birlikte bu parametrelerin sepsiste buzağllarda prognostik indikatör olarak öneminin ortaya konulabilmesi için daha çok sayıda hayvanda, daha sik örnekleme ile yapılacak kontrollü çalışmalara ihtiyaç vardır.

\section{Teşekkür}

Bu araştırma Mehmet Akif Ersoy Üniversitesi Bilimsel Araştırma projeleri Koordinatörlüğü tarafindan 0467-YL-17 proje numarası ile desteklenmiştir.

\section{Kaynaklar}

Al-Khafaji, A.H., Pinsky, M.R., 2017. Multiple AlKhafaji, A.H., Pinsky, M.R., 2017. Multiple Organ Dysfunction Syndrome in Sepsis, http://emedicine.medscape.com/article/169640overview.(10.03.2016).

Angus, D.C., Van der Poll, T., 2013. Severe sepsis and septic shock. The New England Journal of Medicine, 369(9):840-851.

Asati, C.K., Roy, S. and Roy, M., 2008. Haematobiochemical study and diagnosis in calves. Intas-Polivet, 2, 245-248.

Aydoğdu, U., Güzelbekteş, H., 2018. Effect of colostrum composition on passive calf immunity in primiparous and multiparous dairy cows. Veterinarni Medicina, 63,1-11 
Basoglu., A., Baspinar, N., Tenori, L., Hu, X., Yildiz, R., 2014. NMR Based Metabolomics Evaluation in Neonatal Calves with Acute Diarrhea and Suspected Sepsis: A New Approach for Biomarker/S Metabolomics, 4, 1-6.

Başer, D.F., Civelek, T., 2013. Correlations between venous acid-base status and renal function in neonatal calves with acute diarrhea. Kocatepe Veterinary Journal, 6, 25-31

Bedenice, D.C., 2016. Overview of Management Of the neonate in Large Animals. Merck Veterinary Manual $11^{\text {th }}$ edition, http://www.merckvetmanual.com/management-andnutrition.(16.5.2017).

Bednarski, M., Kupczynski, R., Sobiech, P., 2015. Acid-base disorders in calves with chronic diarrhea. Polish Journal of Veterinary Sciences., 18, 207-215.

Bozukluhan, K., Merhan, O., Gökçe, H.İ., Deveci, H.A., Gökçe, G., Ongun, M., Maraşlı, Ş., 2017. Alterations in lipid profile in neonatal calves affected by diorrhea. Veterinary World, 10, 786-789.

Brar, A.P.S., Sood, N.K., Ahuja, C.S., Sandhu, B.S., Gupta, K., Singh, C.K., 2014. Serum biochemical changes in neonatal diarrhoeic calves of different age groups. Indian Journal of Veterinary Pathology, 38, 1417.

Brar, T.K., Singh, K.D., Kumar, A., 2015. Effect of different phases of menstrual cycle on heart rate variability (HRV). Journal of Clinical and Diagnostic Research, 9, 1-4.

Cho Y-il, Yoon K-jin 2014. An overview of calf diarrhea-infectious etiology, diagnosis, and intervention. Journal of Veterinary Sciences, 15 (1), 117.

Constable, P.D., Hinchcliff, K.W., Done, S.H., Grünberg, W., 2016. Veterinary Medicine, 11 th ed, Saunders Ltd. China, p: 57-67.

Egli, C.P., Blum, J.W., 1998. Clinical, haematological, metabolic and endocrine traits during the first three months of life of suckling simmentaler calves held in a cow-calf operation. Zentralbl Veterinarmed A., 45, 99118.

Fecteau, G., Pare, J., Van Metre, D.C., Smith, B.P., Holmberg, C.A., Guterbock, W., Jang S., 1997. Use of a clinical sepsis score for predicting bacteremia in neonatal dairy calves on a calf rearing farm. Canadian Veterinary Jornal, 38, 101-104.

Fecteau, G., Smith, B.P., George, L.W., 2009. Septicemia and meningitis in the newborn calves.
Veterinary Clinics of North America, Food Animal Practice, 25, 195-208.

Gasparavic, V., Dakovic, K., Gornik, I., Radonic, R., 2014. Severe Acute Pancreatitis as a Part of Multiple Dysfunction Syndrome. Collegium Antropologicum, 38, 125-128.

Himanshu, 2010. Clinico-pathologic and therapeutic studies on enteritis in neonatal calves. Department of Veterinary Medicine, CSK Himachal Pradesli Krislii Vishvavidyalaya PaIampur-176 062 (H.P.) India.

House, A.M., Irsik, M., Shearer, J.K., 2008. Sepsis, Failure of Passive Transfer, and Fluid Therapy in Calves.1 Veterinary Medicine-Large Animal Clinical Sciences Department publications, http://www.calfology.com, p: 1-5.

Jezek, J., 2007. The dynamics of serum immunoglobulin concentrations and hematological and biochemical parameters in the period to the age of 24 weeks in diferently reared calves, p: 172, Univerza v Ljubljani, Veterinarska fakulteta, Ljubljana, Slovenija.

Jezek, J., Klocic, M., Klinkon, M., 2006. Influence of age on biochemical parameters in calves. Bulletin of the Veterinary Institute in Pulawy, 50, 211-214.

Kaneko, J..J, Harvey, J.W., Bruss, M.L., 2008. Clinical Biochemistry of Domestic Animals. p: $364-$ 390.6th ed. Academic Press, New York. ABD.

Kaneko, J.K., 1997. Clinical biochemistry of domestic animals, 5th ed, Academic pres, San Diego, p: 413.

Kaur, K., Randhawa, S.S., Chhabra, S., 2006. Haemato-biochemical profile of diarrhoeic dairy calves affected with colibacillosis. Indian Journal of Veterinary Medicine, 26, 9-11.

King, E.G., Bauza, G.J., Mella, J.R., Remick, D.G ., 2014. Pathophysiologic mechanisms in septic shock. Labaoratory Investigation, 94, 4-12.

Klinkon, M., Jezek, J., 2012. Volues of blood variables in calves. 302-320. https://www.researchgate.net/publication/290488632 Values of blood variables in calves.

Knowles, T.G., Edwards, J.E., Bazeley, K.J., Brown, S.N., Butterworth, A., Warriss, R.D., 2000. Changes in the blood biochemical and haematological profile of neonatal calves with age. Veterinary Record, $147,593-598$.

Kumar, S., Jakhar, K.K., Nehra, V., Singh, S., 2018. Alterations of haemato-biochemical and oxidative stress parameter in diarrhoeic buffalo calves. The Pharma Innovation Journal, 7, 195-197. 
Kurz, M.M., Willett, L.B., 1991. Carbonhydrate, enzyme, and hematology Dynamics in newborn calves. Journal of Dairy Sciences., 74, 2109-2118.

Lassen, E.D., 2004. Laboratory evaluation of plasma and serum proteins. In: Thrall MA, editor. Veterinary hematology and clinicalchemistry. Philadelphia (PA): Lippincott Williams \&Wilkins, p: 401-415.

Lofstedt, J., Dohoo, I.R., Duizer, G., 1999. Model to predict septicemia in diarrheic calves. Journal of Verterinary Internal Medicine, 13, 81-8.

Maach, L., Grunder, H.D., Boujya, A., 1992. Clinical and haematological investigations in new born Holstein Friesian calves with diarrhea in Morocco. Deutsche Tierarztliche Wochenschrfi, 99, 133-140.

Maden, M., Birdane, F.M., Altunok, V., Dere, S., 2004. Serum and colostrum/milk alkaline phosphatase activities in the determination of passive transfer status in healty lambs. Revue de Medecine Veterinaire, 155, 565-569.

Martin, G.S., Mannino, D.M., Eaton, S., Moss M., 2003. The epidemiology of sepsis in the United States from 1979 through 2000. The New England Journal of Medicine 348, 1546-1554.

McGuirk, S.M., 2011. Management of Dairy Calves from Birth to Weaning. Ed (s): Risco, CA, Retemal PM, Dairy Production Medicine, Wiley -Blackwell, West Sussex, p: 175-182.

Merx, M.W., Weber, M.D., 2007. Sepsis and the Heart. Circulation, 116, 793-802.

Mohri, M., Sharifi, K., Eidi, S., 2007. Hematology and serum biochemistry of Holstein dairy calves: Age related changes and comparison with blood composition in adults. Research in Veterinary Sciences, 83, 30-39.

Muri, C., Schottstadt ,T., Hammon, H.M., Meyer, E., Blum, J.W., 2005. Hematological. Metabolic and endocrine effects of feedning vitamin A and lactoferin in neonatal calves. Journal of Dairy Science, 88, 1062 1077.

Osterbur, K., Mann, F.A., Kuroki, K., DeClue, A., 2014. Multiple Organ Dysfunction Syndrome in Humans and Animals. Journal of Veterinary Internal Medicine, 28, 1141-1151.

Pardon, B., Deprez, P., 2018. Rational antimicrobial therapy for sepsis in cattle in face of the new lagislation on critically important antimicrobials. Vlaams Diergeneeskundig Tijdschrift, 87, 37-46.

Pekcan, M., Fidanc1, U.R., Yüceer, B., Özbeyaz, C., 2013. Estimation of passive immunity in newborn calves with routine. Ankara Üniviversitesi Veteriner Fakültesi Dergisi, 60, 85-88.

Poulsen, K.P., Foley, A.L., Collins, M.T., McGuirk, S.M., 2010. Comparison of passive transfer of immunity in neonatal dairy calves fed colostrum or bovine serum-based colostrum replacement and colostrum supplement products. Journal of American Veterinary Medical Association, 237, 949-954.

Rastawicki, W., Paradowska-Stankiewicz, I., Stefanoff, P., Zasada, A.A., 2011. Reliability of the cut-off value in the routine serodiagnosis of pertussis performed by the commercial ELISA assays. Medycyna Doświadczalnai Mikrobiologia, 63, 73-80.

Santos, R.L., Renee, M., Baumler, J. and Adams, L., 2002. Hematologicand serum biochemical changes in Salmonella ser Typhimurium-infectedcalves. American Journal of Veterinary Research, 63, 1145-115.

Singh, M., Gupta, V.K., Mondal, D.B., Bansal, S.K., Sharma, D.K., Shakya, M., Gopinath, D., 2014. A study on alteration in haemato-biochemical parameters in Colibacillosis affected calves. International Journal of Advanced Research, 2, 746750 .

Smith, B.P., 2015. Large Animal Internal Medicine, $5^{\text {th }}$ edition, Elsevier Press, Missouri, p 221-339.

Sobiech, P., Kuleta, Z., 2006. Activity of LDH isoenzymes in diarrhoeic calves. Bulletin of the Veterinary Institute in Pulawy, 50, 401-404.

Şen İ., Güzelbekteş H., Yildiz R., 2013. Neonatal Calf Diarrhea: Pathophysiology, Epidemiology, Clinic, Treatment And Protection. Turkiye Klinikleri Journal of Veterinary Sciences, 4, 71-78.

Thomas H.S., 2014., Septicemia and Toxemia in Calves, Angus Beef Bulletin, 7, 1.

Tothova, C., Nagy, O., Kovac, G., Nagyova, V., 2016. Changes in the concentratios of serum proteins in calves during the first month of life. Journal of Applied Animal Research, 44, 338-346.

Tyler, J.W., Hancock, D.D, Wiksie, S.E., Holler, S.L., Gay, J.M., Gay, CC., 1998. Use of serum protein concentration to predict mortality in mixed-source dairy replacement heifers. Journal of Veterinary Internal Medicine, 12, 79-83.

Vincent, J.L., Sakr, Y., Sprung, C.L., 2006. Sepsis in Europeanintensivecareunits: results of the SOAP study. Critical Care Medicine, 34, 344-353.

Yıldız R., Beslek M., Beydilli Y., Özçelik M., Biçici Ö., 2018. Evaluation of Platelet Activating Factor İn Neonatal Calves With Sepsis. Veteriner Hekimler Derneği Dergisi, 89, 66-73. 